\title{
Penerapan pembelajaran matematika melalui problem posing-stad untuk meningkatkan kemampuan berpikir kreatif siswa kelas VIII SMPN 1 Dampit
}

\author{
Nur Kharisma Widya Agustin, Cholis Sa'dijah* \\ Universitas Negeri Malang, Jl. Semarang No. 5 Malang, Jawa Timur, Indonesia \\ *Penulis korespondensi, Surel: cholis.sadijah.fmipa@um.ac.id
}

Paper received: 01-09-2021; revised: 15-09-2021; accepted: 30-08-2021

\begin{abstract}
This research is a classroom action research. This research was intended to describe the stages of learning that use problem posing-STAD to increasing the students' creative thinking ability. The results of this research indicate that mathematics learning use problem posing-STAD can increase students' creative thinking ability so that students can show up new ideas which are a combination of the previous ideas through learning steps as a means: (1) preliminary activities, (2) core activities are consisting of six activities, that is, preparation of group activities, literacy activities, group discussion activities, presentation activities resulting from group discussions, problem posing activities, and presentation of results of problem posing, and (3) closing activities.
\end{abstract}

Keywords: problem posing; STAD; creative thinking

\begin{abstract}
Abstrak
Penelitian ini merupakan penelitian tindakan kelas. Tujuan penelitian ini adalah untuk mendeskripsikan langkah-langkah pembelajaran problem posing-STAD dalam meningkatkan kemampuan berpikir kreatif siswa. Hasil penelitian ini menunjukkan bahwa pembelajaran matematika melalui problem posing-STAD dapat meningkatkan kemampuan berpikir kreatif siswa sehingga siswa dapat memunculkan gagasan baru yang merupakan gabungan dari ide sebelumnya yaitu dengan langkah-langkah pembelajaran sebagai berikut: (1) kegiatan pendahuluan, (2) kegiatan inti yang terdiri dari enam kegiatan, yaitu persiapan kegiatan berkelompok, kegiatan literasi, kegiatan diskusi kelompok, kegiatan presentasi hasil diskusi kelompok, kegiatan pengajuan masalah (problem posing), dan kegiatan presentasi hasil pengajuan masalah, serta (3) kegiatan penutup.
\end{abstract}

Kata kunci: problem posing; STAD; berpikir kreatif

\section{Pendahuluan}

Matematika merupakan salah satu mata pelajaran yang dipelajari mulai dari bangku sekolah dasar sampai dengan perguruan tinggi yang dapat mengembangkan kreativitas berpikir siswa. Hal ini sesuai dengan pendapat Sa'dijah (2013) yaitu matematika mempunyai peran penting dalam pemecahan masalah dan mengambil keputusan karena dengan belajar matematika dapat melatih seseorang untuk berpikir logis dan kreatif. Selain itu, menurut Arsyad, dkk., (2016) matematika dapat melatih manusia untuk berpikir dan bernalar untuk menyelesaikan masalah dengan berpikir logis yang menggunakan logika tertentu dan bersifat analitis. Dengan demikian, pembelajaran matematika mempunyai peran penting dalam proses perkembangan kemampuan berpikir kreatif siswa.

Berdasarkan hasil wawancara dengan salah satu guru matematika di SMPN 1 Dampit tanggal 18 Oktober 2018 guru menggunakan satu model pembelajaran matematika yang dianggap dapat mengejar target kurikulum agar siswa dapat menyelesaikan materi tepat waktu. Guru menganggap apabila menggunakan berbagai model pembelajaran pada 
pembelajaran matematika dapat membuat alokasi waktu yang direncanakan dalam rencana pelaksanaan pembelajaran (RPP) tidak sesuai dengan waktu pelaksanaan. Peneliti juga melaksanakan observasi di SMPN 1 Dampit pada tanggal 24 dan 25 Oktober 2018 di kelas IX D, VIII A dan VIII B, pada pembelajaran matematika guru lebih aktif daripada siswa. Guru lebih banyak memberi pertanyaan agar siswa memikirkan asal dari rumus yang telah ditemukan. Walaupun guru telah memberikan pertanyaan yang dapat membangun pengetahuan siswa, sayangnya hanya beberapa siswa saja yang aktif dalam mengajukan jawaban. Ketika guru memberi siswa soal dengan cara penyelesaian sama dengan soal yang telah dibahas oleh guru, siswa dapat mengerjakan soal dengan waktu yang singkat. Namun ketika siswa diberi soal berbeda dari soal yang telah dijelaskan guru, siswa kesulitan sehingga membutuhkan waktu sedikit lebih lama serta menunggu bantuan guru dalam menyelesaikan soal. Guru membantu siswa memecahkan masalah dengan mengingatkan kembali rumus-rumus yang sudah dipelajari. Guru kurang memberi pertanyaan-pertanyaan pancingan agar siswa dapat memikirkan sendiri cara memecahkan masalah yang diberikan. Selain itu, dalam mengukur kemampuan berpikir kreatif siswa, guru hanya melihat bagaimana cara penyelesaian masalah siswa. Apabila siswa memecahkan masalah sesuai dengan prosedur yang sudah dicontohkan guru dan menjawab dengan benar maka guru menganggap bahwa siswa sudah berpikir kreatif. Hal ini menandakan kurang tumbuhnya kemampuan berpikir kreatif matematika siswa dan kurangnya pemahaman guru dalam mengukur kemampuan berpikir kreatif siswa.

Pengertian berpikir kreatif menurut Huljannah (2018) adalah suatu kegiatan mental yang dapat menghasilkan hal berbeda dari yang lain. Menurut Sigit, dkk., (2019) siswa yang memiliki kemampuan berpikir kreatif akan menemukan banyak cara dalam memecahkan solusi dari permasalahan yang dihadapi. Berpikir kreatif siswa tidak lepas dari pemecahan masalah dan pengambilan keputusan. Menurut Crespo \& Sinclair (2008), salah satu aktivitas matematika yang dapat mendorong kreativitas siswa adalah pengajuan masalah matematika. Kelebihan dari pengajuan masalah (problem posing) menurut Christou, dkk., (2005) adalah dapat memberikan manfaat untuk siswa dalam memecahkan soal cerita dan dengan pembelajaran problem posing dapat membantu guru untuk mengetahui pemahaman siswa tentang konsep matematika. Silver (1994) menjelaskan hubungan kreativitas dengan pengajuan masalah menggunakan tiga komponen utama dalam "The Torrance Test of Creative Thinking (TTCT)" yaitu kompenen kelancaran (fluency), fleksibilitas (flexibility) dan kebaruan (novelty).

Selain pembelajaran menggunakan strategi problem posing, kemampuan berpikir kreatif siswa dapat didorong dengan adanya diskusi kelompok. Dalam diskusi kelompok setiap siswa mau belajar dari siswa yang lain dan setiap siswa bisa menjadi sumber belajar. Salah satu model pembelajaran kooperatif adalah model Student Team Achievement Division (STAD). Model pembelajaran kooperatif tipe STAD dapat dikombinasikan dengan strategi pembelajaran problem posing. Kombinasi pendekatan problem posing dengan model pembelajaran STAD disebut dengan problem posing-STAD. Pembelajaran ini merupakan pembelajaran yang mengadaptasikan kemampuan siswa yang difokuskan pada pembangunan pengetahuan siswa sehingga mampu untuk berpikir kreatif dengan cara meningkatkan pengetahuannya dalam merumuskan pertanyaan. Oleh karena itu, pembelajaran matematika melalui problem posing-STAD dapat mengatur siswa agar saling membantu dan saling bertukar pendapat dalam mengajukan masalah dan menyelesaikan masalah. 
Atas dasar berbagai uraian yang telah diungkapkan di atas. Peneliti akan menerapkan pembelajaran model Problem Posing-STAD pada siswa kelas VIII. Oleh karena itu skripsi ini ditulis dengan judul "Penerapan Pembelajaran Matematika melalui Problem Posing-STAD untuk Meningkatkan Kemampuan Berpikir Kreatif Siswa Kelas VIII SMPN 1 Dampit".

\section{Metode}

Penelitian ini merupakan penelitian tindakan kelas yang bertujuan untuk mendeskripsikan langkah-langkah pembelajaran problem posing-STAD dalam meningkatkan kemampuan berpikir kreatif siswa. Penelitian tindakan kelas dalam penelitian ini dilaksanakan dengan tahapan menurut Hendriana \& Afrilianto (2017) yaitu perencanaan (planing), tindakan (acting), pengamatan (observation) dan refleksi (reflecting). Peneliti memiliki peran sebagai pemberi tindakan sekaligus observer. Peneliti sebagai perencana kegiatan, pelaksana pembelajaran, pengumpul data, penganalisis dan pelapor hasil penelitian. Peneliti sebagai observer melaksanakan observasi dengan bantuan guru kelas dan teman sejawat. Observasi dilakukan untuk mengobservasi aktivitas guru dan aktivitas siswa selama proses pembelajaran. Penelitian ini dilaksanakan di SMP Negeri 1 Dampit. Waktu pelaksanaan penelitian pada semester genap tahun ajaran 2018/2019, dengan subjek penelitian adalah siswa kelas VIII C SMP Negeri 1 Dampit.

Instrumen penelitian merupakan alat untuk mengumpulkan data. Instrumen yang digunakan dalam penelitian ini yaitu, (1) lembar validasi, (2) lembar observasi aktivitas guru, (3) lembar observasi aktivitas siswa, (4) tes, dan (5) lembar catatan lapangan. Lembar validasi yang dibuat peneliti meliputi lembar validasi Rencana Pelaksanaan Pembelajaran (RPP), lembar validasi Lembar Kegiatan Siswa yang terdiri dari (LKS, lembar problem posing), lembar validasi tes, lembar validasi lembar observasi guru, dan lembar validasi lembar observasi siswa. Lembar observasi yang dibuat peneliti meliputi lembar observasi aktivitas guru dan lembar observasi aktivitas siswa. Lembar observasi aktivitas digunakan untuk mengetahui aktivitas guru dan siswa terkait keterlaksanaan pembelajaran problem posingSTAD. Tes pada penelitian ini diberikan setiap akhir pertemuan dan setiap akhir siklus. Tes di akhir siklus digunakan sebagai alat ukur berpikir kreatif siswa setelah diterapkan pembelajaran dengan problem posing-STAD. Lembar catatan lapangan digunakan untuk mengumpulkan data terkait proses pembelajaran yang tidak terekam pada lembar observasi. Misalnya kegiatan alternatif yang dilakukan guru ketika alokasi waktu tidak sesuai dengan yang direncanakan atau hal-hal yang dilakukan guru untuk mengatasi permasalahan pada proses pembelajaran.

Langkah-langkah yang ditempuh dalam proses pengumpulan data dalam penelitian ini adalah mengumpulkan data hasil validasi, mengumpulkan data hasil observasi aktivitas guru dan siswa, mengumpulkan data kemampuan berpikir kreatif siswa, serta mengumpulkan data lembar catatan lapangan.

Teknik analisis data yang digunakan dalam penelitian ini adalah analisis data kualitatif dan kuantitatif. Tahap pertama adalahreduksi data, reduksi data dilakukan dengan cara memilah data yang diperoleh. Data yang diambil merupakan data yang sesuai dan mendukung tujuan penelitian, yaitu dapat meningkatkan kemampuan berpikir kreatif siswa dalam pembelajaran matematika melalui penerapan Problem Posing -STAD. Selanjutnya adalah penyajian data. Data yang telah diseleksi kemudian disajikan dengan cara menyusun hasil reduksi. Hasil reduksi berupa sekumpulan informasi yang telah diperoleh secara naratif, 
yaitu diuraikan dengan kalimat verba sehingga memungkinkan untuk membuat kesimpulan. Tahap terakhir dalam analisis data adalah penarikan kesimpulan. Kesimpulan sebagai pendukung dalam mengukur keberhasilan data dianalisis.

Pelaksanaan tindakan dilakukan sebanyak tiga pertemuan setiap siklus. Tahap tindakan dilakukan dengan menerapkan pembelajaran problem posing-STAD dan dilaksanakan sesuai dengan pelajaran matematika siswa kelas VIII C SMPN 1 Dampit semester genap tahun ajaran 2018/2019. Materi yang digunakan adalah materi lingkaran. Waktu pembelajaran setiap pertemuan ada yang berlangsung $2 \times 40$ menit dan ada yang $3 \times 40$ menit. Proses pembelajaran dilaksanakan dengan mengacu RPP yang telah disusun.

Krieteria yang digunakan untuk mengukur keberhasilan dalam penelitian ini adalah sebagai berikut. (1) Persentase siswa yang mendapatkan kriteria penilaian berpiki kreatif minimal "kreatif" pada tes akhir siklus minimal 80\% dari jumlah siswa. (2) Hasil kriteria keterlaksanaan aktivitas guru berdasarkan lembar observasi aktrivitas guru minimal dalam kategori baik. (3) Hasil kriteria keterlaksanaan aktivitas siswa berdasarkan lembar observasi aktivitas siswa minimal dalam kategori baik. Apabila di akhir siklus penelitian tidak memenuhi kriteria keberhasilan tindakan, maka penelitian akan dilanjutkan pada siklus berikutnya dengan mempertimbangkan analisis data dan refleksi untuk memperbaiki siklus selanjutnya.

\section{Hasil dan Pembahasan}

\subsection{Hasil}

Perangkat pembelajaran dan instrumen penelitian divalidasi oleh validator ahli, yaitu guru besar pendidikan matematika Universitas Negeri Malang. Perangkat pembelajaran dan instrumen penelitian dinyatakan valid oleh validator dan siap digunakan untuk penelitian.

Pelaksanaan tindakan (acting) siklus I terdiri dari 3 pertemuan. Dua pertemuan digunakan untuk pembelajaran problem posing-STAD, dan satu pertemuan digunakan untuk tes kemampuan berpikir kreatif siswa atau tes akhir siklus I. Pertemuan pertama berlangsung 2x40 menit di ruang kelas VIII C SMP Negeri 1 Dampit. Indikator pencapaian kompetensi yang akan dicapai siswa pada pertemuan pertama adalah (1) mendeskripsikan unsur-unsur lingkaran, dan (2) menjelaskan hubungan antar unsur pada lingkaran. Pertemuan kedua 3x40 menit di ruang kelas VIII C SMP Negeri 1 Dampit. Indikator pencapaian kompetensi yang akan dicapai siswa pada pertemuan kedua adalah (1) menentukan hubungan antara sudut pusat dan sudut keliling, (2) menentukan hubungan antara sudut pusat dan panjang busur lingkaran, (3) menentukan hubungan antara sudut pusat dan luas juring lingkaran, dan (4) menentukan hubungan antara panjang busur dan luas juring lingkaran. Pertemuan ketiga berlangsung $2 \times 40$ menit di ruang kelas VIII C SMP Negeri 1 Dampit. Guru mengadakan tes akhir siklus I. Tes akhir siklus I berisi 5 nomor. Setiap nomor pada lembar tes meminta siswa untuk membuat minimal 3 soal beserta penyelesaiannya terkait unsur-unsur lingkaran, hubungan antar unsur lingkaran, hubungan sudut pusat dan sudut keliling lingkaran, serta hubungan sudut pusat, panjang busur dan luas juring lingkaran.

Aktivitas guru pada pelaksanaan tindakan siklus I memperoleh rata-rata persentase observasi sebesar 95,46\%. Hal ini menunjukkan bahwa aktivitas guru dalam kategori sangat baik. Dengan demikian keterlakasanaan aktivitas guru pada pembelajaran problem posing- 
STAD telah memenuhi kriteria keberhasilan tindakan. Rata-rata persentase observasi aktivitas siswa pada pembelajaran problem posing-STAD siklus I adalah 90,69\%. Rata-rata tersebut menunjukkan bahwa aktivitas siswa dalam kategori sangat baik. Oleh karena itu, keterlaksanaan aktivitas siswa berdasarkan hasil observasi telah memenuhi kriteria keberhasilan tindakan. Berdasarkan analisis hasil tes akhir siklus I yaitu tes kemampuan berpikir kreatif siswa kelas VIII C menunjukkan 12 siswa mendapat kategori kreatif atau sangat kreatif, 18 siswa mendapat kategori cukup kreatif atau kurang kreatif dan 2 siswa tidak mengikuti tes. Dengan demikian disimpulkan bahwa siklus I belum memenuhi kriteria keberhasilan tindakan. Hal ini dikarenakan persentase siswa yang mendapatkan penilaian berpikir kreatif minimal "kreatif" pada tes akhir siklus adalah 37,5\% dan belum mencapai persentase minimal yaitu $80 \%$ dari jumlah siswa. Oleh karena itu, pelaksanaan pembelajaran siklus I belum dapat dikatakan berhasil sehingga peneliti melanjutkan penelitian pada siklus II.

Pelaksanaan tindakan (acting) siklus II terdiri dari 3 pertemuan. Dua pertemuan digunakan untuk pembelajaran problem posing-STAD, dan satu pertemuan digunakan untuk tes akhir siklus II untuk mengetahui kemampuan berpikir kreatif siswa. Peneliti melaksanakan pertemuan pertama siklus II berlangsung $2 \times 40$ menit di ruang kelas VIII C SMP Negeri 1 Dampit. Indikator pencapaian kompetensi yang akan dicapai siswa pada pertemuan pertama siklus II adalah (1) menentukan rumus keliling lingkaran, dan (2) menentukan pendekatan nilai phi. Pertemuan kedua siklus berlangsung $3 \times 40$ menit di ruang kelas VIII C SMP Negeri 1 Dampit. Indikator pencapaian kompetensi yang akan dicapai siswa pada pertemuan kedua siklus II adalah menentukan rumus luas lingkaran serta menentukan solusi dari masalah yang berkaitan dengan luas lingkaran. Pertemuan ketiga tes akhir siklus II berlangsung 2x40 menit di ruang kelas VIII C SMP Negeri 1 Dampit. Tes akhir siklus II digunakan untuk mengukur kemampuan berpikir kreatif siswa setelah melaksanakan pembelajaran problem posing-STAD. Lembar tes siklus II berisi 4 soal dengan pendekatan problem posing, dimana tiap soal mengarahkan siswa untuk membuat minimal 3 soal beserta penyelesaiannya dari suatu situasi atau gambar. Soal tersebut berkaitan dengan materi yang dipelajari pada siklus II, yaitu tentang keliling dan luas lingkaran. Soal pada lembar tes memberikan kesempatan siswa untuk mengganti bilangan, mengganti variabel, dan mengubah kalimat biasa menjadi kalimat matematika.

Rata-rata persentase aktivitas guru pada pelaksanaan tindakan siklus II adalah 95,97\%. Persentase tersebut menunjukkan bahwa aktivitas guru dalam kategori sangat baik. Dengan demikian hasil observasi aktivitas guru pada pembelajaran problem posing-STAD telah memenuhi kriteria keberhasilan tindakan. Hasil observasi aktivitas siswa pada pembelajaran problem posing-STAD siklus II memperoleh rata-rata persentase observasi sebesar 90,94\%. Persentase rata-rata hasil observasi tersebut menunjukkan bahwa aktivitas siswa dalam kategori sangat baik. Oleh karena itu, keterlaksanaan aktivitas siswa berdasarkan hasil observasi siklus II telah memenuhi kriteria keberhasilan tindakan. Berdasarkan analisis hasil tes kemampuan berpikir kreatif siswa pada tes akhir siklus II, 28 siswa mendapat kategori kreatif atau sangat kreatif, 3 siswa mendapat kategori cukup kreatif atau kurang kreatif dan 1 siswa tidak mengikuti tes. Dengan demikian disimpulkan bahwa keterlaksanaan aktivitas guru, keterlaksanaan aktivitas siswa, dan persentase siswa yang mendapat nilai berpikir kreatif minimal "kreatif" pada tes akhir siklus II telah memenuhi kriteria keberhasilan tindakan. Oleh karena itu, penelitian ini berhenti sampai siklus II. 


\subsection{Pembahasan}

Pembelajaran problem posing-STAD terdiri dari tiga kegiatan, yaitu kegiatan pendahuluan, kegiatan inti, dan kegiatan penutup. Pada kegiatan pendahuluan, guru membuka pembelajaran dengan mengucap salam dan berdoa, dilanjutkan dengan memeriksa kehadiran siswa. Selanjutnya guru menyampaikan apersepsi kepada siswa. Selanjutnya, guru menyampaikan tujuan pembelajaran, aspek-aspek yang akan dinilai dan alur kegiatan pembelajaran.

Kegiatan inti terdiri dari enam tahapan, yaitu (1) persiapan pembelajaran STAD, (2) kegiatan literasi, (3) kegiatan pembelajaran STAD, (4) presentasi LKS, (5) kegiatan problem posing, dan (6) presentasi lembar problem posing. Guru membagi siswa menjadi 8 kelompok heterogen, masing-masing kelompok beranggotakan 4 siswa. Hal ini sesuai dengan Slavin (2005) yang menyatakan bahwa pembelajaran STAD merupakan pembelajaran dimana siswa dibagi menjadi beberapa kelompok belajar yang terdiri dari empat orang yang berbeda-beda tingkat kemampuan, jenis kelamin, latar belakang dan etnisnya. Kelompok heterogen dibuat berdasarkan kemampuan siswa dari nilai ujian akhir semester ganjil. Membentuk kelompok heterogen dapat bermanfaat untuk membantu siswa dengan minat belajar rendah mendapat kemudahan belajar karena antar anggota kelompok dapat saling membantu satu sama lain dalam menyelesaikan masalah dan dalam memahami materi. Menurut Hosnan (2014) model pembelajaran kooperatif tipe STAD berguna untuk menumbuhkan kemampuan kerja sama, kreatif, berpikir kritis dan meningkatkan kepedulian terhadap teman sebayanya.

Pada siklus I, guru membagi kelompok berdasarkan nilai ujian akhir semester ganjil dimana pada masing-masing kelompok terdapat siswa yang berkemampuan tinggi, berkemampuan sedang dan berkemampuan rendah serta mendapat rekomendasi dari guru matematika kelas VIII C. Pada siklus II, pembagian kelompok sama dengan siklus I karena dilihat dari tes akhir siklus I siswa yang berkemampuan tinggi, sedang dan rendah sudah terbagi dalam masing-masing kelompok.

Pada kegiatan literasi, siswa diminta untuk membaca materi yang akan dipelajari dari lembar materi yang telah diberikan guru, buku pegangan siswa, ataupun buku penunjang lain. Kemampuan untuk berliterasi yaitu melihat, menyimak, berbicara, membaca dan mencipta. Tujuan literasi adalah untuk menumbuhkan budaya literasi, menumbuhkan budaya membaca dan menulis, meningkatkan karakter serta melaksanakan literasi dalam pembelajaran. Menurut Khotimah, dkk., (2018) literasi informasi merupakan syarat penting untuk mendorong siswa dalam memperoleh informasi dan pengetahuan yang dibutuhkan dalam kehidupannya sebagai bekal dalam menjalani kehidupan.

Sebelum siswa mengerjakan LKS, guru menginstruksikan siswa untuk membaca petunjuk umum pada LKS dan memahami langkah kerja tiap kegiatan. Selanjutnya guru meminta masing-masing kelompok agar membagi penugasan untuk setiap anggota kelompok. Penugasan dalam kelompok meliputi ketua kelompok untuk mengatur jalannya diskusi, siswa yang menerapkan cara kerja pada LKS ke media pembelajaran, dan penulis jawaban. Thobroni (2015:236) menyatakan selama proses pembelajaran berkelompok terdapat diskusi, saling tukar ide dari individu atau kelompok, yang pandai mengajari yang lemah sehingga siswa yang belum tahu menjadi tahu. 
Pada pembelajaran siklus I, terdapat beberapa siswa yang belum memahami betul terkait materi yang dipelajari. Hal ini disebabkan karena siswa tidak mencatat penjelasan guru saat memberikan umpan balik terhadap jawaban siswa yang dipresentasikan. Pada siklus ke II, guru lebih mengingatkan siswa agar mencatat hal-hal penting dalam pembelajaran. Selain itu, guru juga mengontrol setiap kegiatan berkelompok siswa dengan mendatangi masing-masing kelompok. Kelompok yang masih merasa kesulitan bertanya kepada guru dan guru membimbing siswa dengan memberikan pertanyaan-pertanyaan pancingan untuk mengarahkan siswa menyelesaikan masalah pada LKS. Hal ini bersesuaian dengan yang dikatakan Sa'dijah (2013) bahwa bimbingan guru dapat membantu siswa untuk membangun pemahannya dengan matematisasi.

Dalam kelompok belajar setiap siswa mempunyai tanggung jawab untuk menyelesaiakan tugasnya dengan baik. Namun pada saat pembelajaran berkelompok berlangsung, terdapat siswa yang tidak ikut berdiskusi karena bercanda dengan temannya dan membebankan tugasnya kepada temannya yang dianggap lebih pandai. Guru mengatasinya dengan mendatangi dan memberikan motivasi kepada siswa yang tidak ikut berdiskusi. Menurut Thobroni (2015) dalam pembelajaran berkelompok, guru perlu menciptakan suasana belajar yang dapat mendorong siswa merasa saling membutuhkan. Menurut Sudjana (2013:160) guru harus berupaya menimbulkan dan mempertahankan perhatian dan memberikan dorongan siswa dalam melaksanakan kegiatan belajar. Dengan demikian, pemberian motivasi dari guru diperlukan untuk menumbuhkan perasaan saling membutuhkan dalam kelompok.

Tahap selanjutnya adalah presentasi LKS. Presentasi merupakan salah satu komponen utama dalam pembelajaran STAD. Menurut Slavin, (2005) komponen utama dalam pembelajaran STAD ada lima, yaitu presentasi kelas, pembentukan tim, kuis, skor kemajuan individual dan rekognsi tim. Perwakilan kelompok, mempresentasikan hasil diskusinya di depan kelas. Setelah membacakan dan menjelaskan hasil diskusinya kepada temantemannya, guru memberikan reward berupa jajan cokelat kepada perwakilan siswa yang presentasi. Selanjutnya guru menawarkan kepada kelompok lain untuk memberi tanggapan atau masukan. Saat guru menawarkan kelompok lain untuk memberi tanggapan, siswa tidak langsung menyampaikan pendapat kelompoknya apabila mempunyai jawaban yang berbeda dengan jawaban yang dipresentasikan. Oleh sebab itu, guru memberikan pertanyaanpertanyaan pancingan terlebih dahulu agar kelompok lain menyampaikan pendapatnya. Setelah itu, guru memberikan umpan balik terhadap jawaban yang telah dipresentasikan perwakilan siswa dan tanggapan dari kelompok lain.

Kegiatan problem posing adalah kegiatan dimana siswa diminta untuk mengerjakan lembar problem posing secara individu diakhir pembelajaran. Pada lembar problem posing terdapat beberapa soal yang menginstruksikan siswa untuk mengajukan sekaligus menyelesaikan soal dari situasi yang ada pada lembar problem posing. Situasi dapat berupa teks, gambar atau informasi lain sehingga dapat mendukung siswa untuk mengajukan masalah yang berkaitan dengan materi yang dipelajari. Ghasempour, dkk., (2013) menyatakan bahwa dalam pembelajaran problem posing, siswa dapat menerapkan satu atau lebih strategi untuk merumuskan masalah baru sebagai metode fleksibilitas dan siswa dapat membangun keterampilan pengajuan masalah yang merupakan keterampilan mental dalam menggunakan kondisi yang diberikan dari suatu permasalahan. Pengertian problem posing menurut Siswono (2018) merupakan proses yang didasari pengalaman matematika dan 
siswa membangun penafsirannya sendiri terhadap situasi konkret lalu merumuskannya menjadi masalah matematika yang berarti. Menurut Thobroni (2015:288) pembelajaran problem posing merupakan pembelajaran yang menuntut siswa untuk merumuskan dan membuat soal secara mandiri. Soal pada lembar problem posing memberikan kesempatan siswa untuk mengganti bilangan, mengganti variabel, dan mengubah kalimat biasa menjadi kalimat matematika.

Dalam mengerjakan lembar problem posing, beberapa siswa masih menggunakan kalimat-kalimat yang ambigu dalam mengajukan soal. Siswa masih kebingungan dalam memilih kata yang tepat ataupun dalam menuliskan simbol matematika. Pada siklus II, guru lebih mengingatkan kepada siswa agar lebih teliti dalam memilih kata dan lebih berhati-hati dalam menuliskan simbol matematika. Penerapan pembelajaran problem posing menurut Thobroni (2015:292) dapat melatih keterampilan siswa untuk berpikir kreatif dan meningkatkan sikap disiplin.

Setelah waktu mengerjakan lembar problem posing habis, guru menunjuk salah satu siswa untuk mempresentasikan hasil pekerjaannya. Menurut Wardana \& Chandra (2017) ketika siswa berani menyatakan pendapat kepada teman-temannya, hal tersebut akan melatih siswa untuk menggunakan kalimat atau bahasa yang baik dan benar serta bahasa yang mudah dipahami orang lain.

Pada kegiatan penutup, guru bersama siswa menarik kesimpulan dari hasil kegiatan masing-masing pertemuan. Selanjutnya guru menyampaikan materi yang akan dipelajari pada pertemuan selanjutnya dan menginstruksikan siswa agar membawa peralatan untuk digunakan pada pertemuan selanjutnya. Hal ini sesuai dengan Sudjana (2013:152) yang menyatakan bahwa di akhir pembelajaran guru hendaknya memberi tahu pokok materi berikutnya agar siswa dapat mempelajari bahan tersebut dari sumber-sumber yang dimilikinya. Terakhir, guru menutup kegiatan pembelajaran dengan mengucap salam.

Penelitian ini berfokus pada peningkatan kemampuan berpikir kreatif siswa setelah mengikuti pembelajaran problem posing-STAD. Berpikir kreatif menurut Sa'dijah, dkk., (2016) adalah kemampuan menghasilkan ide-ide yang melibatkan aspek berpikir kreatif yakni kefasihan, keluwesan dan keaslian. Menurut Crespo \& Sinclair (2008) pembelajaran matematika dengan pengajuan masalah dapat mendorong kreativitas siswa. Peningkatkan kemampuan berpikir kreatif siswa dalam penelitian ini dilihat dari (1) hasil kriteria keterlaksanaan aktivitas guru berdasarkan lembar observasi aktivitas guru minimal dalam kategori baik, (2) hasil kriteria keterlaksanaan aktivitas siswa berdasarkan lembar observasi aktivitas siswa minimal dalam kategori baik, dan (3) persentase siswa yang mendapatkan kriteria penilaian berpikir kreatif minimal "kreatif" pada tes akhir siklus minimal $80 \%$ dari jumlah siswa.

Pada siklus I, rata-rata persentase hasil observasi aktivitas guru adalah 95,46\% dengan kategori sangat baik. Rata-rata persentase hasil observasi aktivitas siswa adalah 90,69\% dengan kategori sangat baik. Siswa yang mendapat kriteria penilaian berpikir kreatif minimal "kreatif" pada tes akhir siklus I adalah 37,5\% dari jumlah siswa. Berdasarkan analisis tes akhir siklus I terhadap 32 siswa kelas VIII C, menunjukkan bahwa 12 siswa mendapat kategori kreatif atau sangat kreatif, 18 siswa mendapat kategori cukup kreatif atau kurang kreatif, dan 2 siswa tidak mengikuti tes akhir siklus I. 
Pada siklus II, rata-rata persentase hasil observasi aktivitas guru adalah 95,97\% dengan kategori sangat baik. Rata-rata presentasi hasil observasi aktivitas siswa adalah 90,94\% dengan kategori sangat baik. Persentase siswa yang mendapat kriteria penilaian berpikir kreatif minimal "kretaif" pada tes akhir siklus II adalah 87,5\% dari jumlah siswa. Berdasarkan analisis tes kemampuan berpikir kreatif pada tes akhir siklus II dari 32 siswa kelas VIII C, terdapat 28 siswa mendapat kategori kreatif atau sangat kreatif, 3 siswa mendapat kategori cukup kreatif atau kurang kreatif dan 1 siswa tidak mengikuti tes akhir. Saat mengerjakan tes akhir siklus II, waktu yang dibutuhkan siswa untuk mengajukan dan menyelesaiakan soal sudah sesuai dengan alokasi waktu yang ditentukan guru. Mayoritas siswa sudah menggunakan bahasa yang jelas dan menggunakan simbol matematika yang sesuai dalam mengajukan dan menyelesaikan soal.

Faktor pendukung pada pembelajaran problem posing-STAD yang dilaksanakan di kelas VIII C SMPN 1 Dampit antara lain (1) siswa tidak melakukan protes saat guru membentuk kelompok heterogen berdasarkan kemampuan siswa. (2) Siswa cepat dalam beradaptasi dengan pembelajaran berkelompok. (3) Siswa mempunyai karakter patuh dan rasa hormat yang tinggi terhadap guru sehingga guru mudah dalam mengatur siswa.

Kendala yang dihadapi peneliti pada pelaksanaan pembelajaran problem posing-STAD adalah (1) Siswa takut bertanya kepada guru apabila mengalami kebingungan dalam memahami instruksi. (2) Terdapat beberapa siswa yang tidak memperhatikan dalam diskusi kelompok ataupun diskusi kelas. (3) Siswa belum terbiasa dalam mengajukan dan menyelesaikan soal sehingga membutuhkan waktu lebih lama dari alokasi waktu yang ditentukan guru. (4) Masih sedikit siswa yang memberi tanggapan terhadap jawaban yang dipresentasikan siswa lain

\section{Simpulan}

\subsection{Kesimpulan}

Hasil penelitian ini menunjukkan bahwa pembelajaran matematika melalui problem posing-STAD dapat meningkatkan kemampuan berpikir kreatif siswa sehingga siswa dapat memunculkan gagasan baru yang merupakan gabungan dari ide sebelumnya yaitu dengan langkah-langkah pembelajaran sebagai berikut: (1) kegiatan pendahuluan, (2) kegiatan inti yang terdiri dari enam kegiatan, yaitu persiapan kegiatan berkelompok, kegiatan literasi, kegiatan diskusi kelompok, kegiatan presentasi hasil diskusi kelompok, kegiatan pengajuan masalah (problem posing), dan kegiatan presentasi hasil pengajuan masalah, serta (3) kegiatan penutup.

Pelaksanaan pembelajaran melalui problem posing-STAD diawali dengan guru membuka pembelajaran dengan mengucap salam dan berdoa, dilanjutkan dengan mengecek kehadiran siswa, menyampaikan materi apersepsi, tujuan pembelajaran, aspek-aspek yang akan dinilai dan alur kegiatan pembelajaran. Selanjutnya guru membagi siswa menjadi 8 kelompok heterogen masing-masing beranggotakan 4 siswa. Setelah siswa berkumpul dengan kelompoknya, siswa diminta untuk membaca materi di lembar materi yang telah diberikan guru ataupun buku pegangan siswa dari sekolah. Selanjutnya, guru meminta agar masing-masing kelompok membagi penugasan untuk setiap anggota kelompok. Selama kegiatan berkelompok, guru membimbing siswa dengan mendatangi setiap kelompok dan membantu kelompok yang kesulitan dalam memahami intruksi pada LKS dengan pertanyaan-pertanyaan pancingan. Selanjutnya perwakilan siswa mempresentasikan hasil 
diskusinya tiap kegiatan yang ada di LKS. Setelah perwakilan kelompok mempresentasikan hasil diskusinya, guru memberikan reward kepada siswa yang maju. Setelah itu, guru menawarkan kepada siswa lain untuk memberi tanggapan terhadap jawaban yang telah dipresentasikan. Selanjutnya, guru memberikan umpan balik terhadap jawaban dan tanggapan siswa.

Setelah kegiatan diskusi kelompok adalah kegiatan pengajuan masalah. Kegiatan pengajuan masalah (problem posing) adalah kegiatan dimana setiap siswa diminta untuk mengerjakan lembar problem posing dalam kelompok. Pada lembar problem posing terdapat beberapa soal yang menginstruksikan siswa agar membuat soal beserta penyelesaiannya dari suatu situasi. Situasi pada lembar problem posing berupa gambar, cerita atau informasi lain terkait materi lingkaran. Setelah siswa mengerjakan lembar problem posing, kegiatan selanjutnya adalah presentasi lembar problem posing. Terakhir adalah kegiatan penutup, guru menarik kesimpulan bersama siswa terkait kegiatan yang sudah dilakukan pada tiap pertemuan sesuai dengan indikator pembelajaran. Selanjutnya, guru menyampaikan materi yang akan dipelajari dan menginstruksikan siswa agar membawa peralatan untuk kegiatan pada pertemuan selanjutnya. Guru menutup kegiatan pembelajaran dengan mengucap salam.

Penerapan pembelajaran matematika melalui problem posing-STAD seperti yang diuraikan di atas dapat meningkatkan kemampuan berpikir kreatif siswa. Hal ini ditunjukkan dengan terpenuhinya kriteria keberhasilan tindakan yang telah ditetapkan yaitu (1) persentase siswa yang mendapatkan kriteria penilaian berpikir kreatif minimal "kreatif" pada tes akhir siklus minimal 80\% dari jumlah siswa, (2) hasil kriteria keterlaksanaan aktivitas guru berdasarkan lembar observasi aktivitas guru minimal dalam kategori baik, dan (3) hasil kriteria keterlakasanan aktivitas siswa berdasarkan lembar observasi aktivitas siswa minimal dalam kategori baik. Kriteria keberhasilan tindakan tercapai pada siklus II karena pada siklus I persentase siswa yang mendapatkan kriteria penilaian berpikir kreatif minimal "kreatif" pada tes akhir siklus belum tercapai.

\subsection{Saran}

Berdasarkan hasil penelitian yang telah dilakukan dengan menerapkan pembelajaran matematika melalui problem posing-STAD dapat dikemukakan saran diantaranya (1) pembagian alokasi waktu tiap kegiatan masih perlu diperhatikan agar pembelajaran berjalan efektif dan sesuai dengan alokasi waktu yang telah direncanakan. (2) Perlu adanya plan B dalam pembagian tugas kelompok serta jalannya pembagian tugas dalam kelompok harus benar-benar dicek kembali oleh guru agar kelompok menjadi lebih aktif. (3) Guru harus memberikan contoh pengajuan masalah yang jelas dari situasi yang disediakan dan mempertegas cara serta ketentuan soal yang dibuat sebelum siswa diminta untuk mengajukan sekaligus menyelesaikan soal.

\section{Daftar Rujukan}

Arsyad, A., Subanji, S., \& Irawati, S. (2016). Berpikir matematis komedian dalam mengonstruksi bahan komedi: studi kasus pada stand up comedy Indonesia. Jurnal Pendidikan: Teori, Penelitian, dan Pengembangan, 1(1), 35-44.

Christou, C., Mousoulides, N., Pittalis, M., Pitta-Pantazi, D., \& Sriraman, B. (2005). An empirical taxonomy of problem posing processes. $Z d m, 37(3), 149-158$.

Crespo, S., \& Sinclair, N. (2008). What makes a problem mathematically interesting? Inviting prospective teachers to pose better problems. Journal of Mathematics Teacher Education, 11(5), 395-415. 
Ghasempour, Z., Bakar, N., \& Jahanshahloo, G. R. (2013). Innovation in teaching and learning through problem posing tasks and metacognitive strategies. International journal of pedagogical innovations, 1(01).

Hendriana, H., \& Afrilianto, M. (2017). Langkah Praktis Penelitian Tindakan Kelas Bagi Guru. Bandung: Refika Aditama.

Hosnan, M. (2014). Pendekatan saintifik dan kontekstual dalam pembelajaran abad 21: Kunci sukses implementasi kurikulum 2013.

Huljannah, M., Sa'dijah, C., \& Qohar, A. (2018). Profil Berpikir Kreatif Matematis Mahasiswa Pendidikan Guru Sekolah Dasar. Jurnal Pendidikan: Teori, Penelitian, dan Pengembangan, 3(11), 1428-1433.

Khotimah, K., \& Sa'dijah, C. (2018). Pelaksanaan Gerakan Literasi Sekolah. Jurnal Pendidikan: Teori, Penelitian, dan Pengembangan, 3(11), 1488-1498.

Sa'dijah, C. (2014). Kepekaan bilangan siswa smp melalui pembelajaran matematika kontekstual yang mengintegrasikan keterampilan berpikir kreatif. Jurnal Pendidikan dan Pembelajaran (JPP), 20(2), 222-227.

Sa'dijah, C., Rafiah, H., Gipayana, M., Qohar, A., \& Anwar, L. (2017). Asesmen pemecahan masalah open-ended untuk mengukur profil berpikir kreatif matematis siswa berdasar gender. Sekolah Dasar: Kajian Teori dan Praktik Pendidikan, 25(2), 147-159.

Silver, E. A. (1997). Fostering creativity through instruction rich in mathematical problem solving and problem posing. $Z d m, 29(3), 75-80$.

Siswono, T. Y. E. (2018). Pembelajaran matematika berbasis pengajuan dan pemecahan masalah. Bandung: Remaja Rosdakarya.

Slavin, R.E. (2005). Coorperatif Learning: Teori, Riset dan Praktik. Bandung: Nusa Media.

Sudjana, N. (2013). Dasar-Dasar Proses Belajar Mengajar. Bandung: Sinar Baru Algensindo.

Thobroni, M. (2015). Belajar dan Pembelajaran: Teori dan Praktik. Yogyakarta: Ar-Ruzz Media.

Wardana, P. E. P. (2016). Penerapan pembelajaran problem posing untuk meningkatkan kemampuan bertanya siswa kelas VII-G SMP Negeri 9 Malang. Penerapan pembelajaran problem posing untuk meningkatkan kemampuan bertanya siswa kelas VII-G SMP Negeri 9 Malang/Putu Evi Paramithasari Wardana. 